\title{
LITERASI AWAL AL-QUR'AN UNTUK ANAK USIA DINI DENGAN TEKNIK READING ALOUD
}

\author{
Eti Nurhayati \\ IAIN Syekh Nurjati Cirebon \\ Email: etinurhayati@syekhnurjati.ac.id. \\ Orcid ld: 0000-0002-1141-2305
}

Article received: 25 February 2019, Review process: 28 February 2019

Article published: 30 March 2019

\begin{abstract}
There are several kinds of methods and techniques to learn Qur'an that have been used and developed extensively for the beginner, including early childhood. Based on this study, there were found at least sixteen methods and eight techniques of Quranic learning. The methods are: Classical Baghdadiyah, Baghdadi ala Malaysia, Barqi, Tilawati, Qira'ati, Iqra, Integrated Iqra, Classical Iqra, Lamma, Nahdhiyah, Wafa, Muyassar, Yanbu'a, Ummi, Rubaiyyat, and Ijmali. The techniques are: Al-Bana, Al-Bayan, Synthetic, Sounding, Repeating, Combination (Seeing, Reading and Writing at once), Talqin, and Reading Aloud. Each method and technique have several advantages and disadvantages. This study was focussed on knowing how the Reading aloud techniques is effectively an efficiently used as an introduction to the early literacy of Qur'an for early childhood. This research used the qualitative descriptive method in the RA Al-Ishlah Bobos Cirebon. This study concludes: (1) The Reading aloud technique is effectively used in the early literacy of Qur'an for early childhood, especieally in the pronouncation of the hijaiyyah letters, lafadz, verse and surah of Qur'an; (2) The Reading aloud technique is efficiently used in the early literacy of Qur'an because it's easy, inexpensive, simple, and flexible to used by the teacher, also attractive to students.
\end{abstract}

Keywords: Early literacy of Qur'an, Early Childhood, Reading aloud technique.

Abstrak
Banyak ragam metode dan teknik pemelajaran al-Qur'an yang telah digunakan dan
berkembang luas di Indonesia untuk para pebelajar pemula, termasuk anak usia dini.
Berdasarkan studi penulis, ditemukan setidaknya enam belas metode dan sembilan teknik
pemelajaran al-Qur'an. Metode-metode tersebut adalah: Baghdadiyah klasik, Baghdadi ala
Malaysia, Barqi, Tilawati, Qira'ati, Iqra, Iqra Terpadu, Iqra Klasikal, Lamma, Nahdhiyah,
Wafa, Muyassar, Yanbu'a, Ummi, Rubaiyat, dan Ijmali. Tekniknya antara lain: Al-Bana, Al-
Bayan, Sintetik, Bunyi, Meniru, Campuran, Libat, Talqin, dan Specch\&Read Aloud (SRA).
Setiap metode dan teknik tersebut memiliki beberapa keunggulan dan kelemahan. Studi ini
difokuskan untuk mengetahui bagaimana efektivitas dan efisiensi teknik Reading aloud
Literasi Awal Al-Quran Untuk Aaak Usia Dini
Dengan Teknik Reading Aloud


digunakan sebagai pengenalan literasi awal al-Qur'an untuk anak usia dini. Penelitian ini menggunakan metode deskriptif kualitatif di RA Al-Ishlah Bobos Cirebon. Kesimpulan penelitian: (1) Teknik Reading aloud sangat efektif digunakan dalam pemelajaran literasi awal al-Qur'an untuk anak usia dini, terutama dalam pengucapan huruf hijaiyyah, lafadz, ayat, dan surah al-Qur'an (2) Teknik Reading aloud sangat efisien digunakan dalam pemelajaran literasi awal al-Qur'an ukarena efisien, mudah, murah, simpel, dan fleksibel digunakan oleh guru, dan menyenangkan bagi anak usia dini.

Kata Kunci: Literasi awal al-Qur’an, Anak Usia Dini, teknik Reading aloud

\section{PENDAHULUAN}

Banyak ragam metode dan teknik pemelajaran al-Qur'an yang berkembang dan telah diimplementasikan luas di Indonesia untuk pemula, termasuk anak usia dini. Kategori "metode" yang dimaksud di sini apabila merupakan suatu sistem pemelajaran secara komprehensif mencakup: kurikulum, syllabus, modul, prinsip, program, persyaratan akademik, kelengkapan administratif, termasuk perencanaan, pelaksanaan, evaluasi program, dan lainlain. Kategori "teknik" apabila hanya merupakan suatu tatacara teknis yang mengatur proses dan hasil pemelajaran. Berdasarkan studi literatur penulis, setidaknya menemukan enam belas metode pemelajaran al-Qur'an, yaitu: Baghdadi Klasik, Al-Baghdadi ala Malaysia, Barqi, Tilawati, Qira'ati, Iqra, Iqra Terpadu, Iqra Klasikal, Lamma, Nahdhiyah, Wafa, Muyassar, Yanbu'a, Ummi, dan Ijmali yang dikembangkan oleh penulis sendiri.

Metode pertama, Baghdadi Klasik. Metode ini merupakan tertua yang pernah diterapkan di Indonesia, berasal dari Baghdad, dikenal di masa pemerintahan Bani Abassiyah, tetapi tidak diketahui dengan pasti siapa penyusunnya, Metode ini dikenal dengan teknik "eja" dimulai dari pengenalan 30 huruf hijaiyyah. Menurut riset Siti Sumihatul Ummah dan Abdul Wafi (2017), Kaidah metode Baghdadi memerlukan 17 langkah, di mana 30 huruf hijaiyyah selalu ditampilkan secara utuh dalam setiap langkah. Semua huruf hijaiyyah tersebut selalu menjadi tema sentral setiap langkah, baik di awal saat mengenal huruf tunggal dengan bunyi asli maupun huruf hijaiyyah yang diberi harakat atau syakal, seperti: fathah, kasrah, dhammah, fathatain, kasratain, dhammatain, alif di akhir, tasydid dan kasrah maddah.

Metode kedua, Baghdadi ala Malaysia. Menurut riset Noornajihan Jaafar (2017) dari Universiti Sains Islam Malaysia (USIM), "Metode al-Baghdadi merupakan satu kaedah 
pemelajaran al-Qur'an terkini yang diasaskan oleh Ustadz Jalaluddin Bin Haji Hasanudddin untuk memenuhi keperluan masyarakat di Malaysia”. Media pemelajaran menggunakan buku modul "Tamhid Al-Baghdadi" dan alat bantu ketuk yang diketuk di papan ketuk berwarna ungu dan kuning. Ketukan di papan kuning menunjukkan perlu dibaca dengan dua intonasi, dan ketukan di papan ungu hanya perlu dibaca dengan satu intonasi. Di samping itu, ada buku pelengkap yaitu "Playtime" berisi seperangkat permainan kreatif menggunakan warna, bentuk, huruf, sebutan huruf, bacaan berintonasi, dan pelbagai aktivitas pemelajaran untuk mengembangkan domain audia, visual, kognitif, afektif, dan psikomotor anak.

Metode ketiga, Barqi. Metode ini diciptakan oleh Muhadjir Sulthan, seorang Dosen Fakultas Adab IAIN Sunan Ampel Surabaya tahun 1965, menggunakan empat teknik: pengamatan struktur kalimat, pemisahan, pemilihan, dan pemanduan. Awalnya metode ini digunakan untuk siswa SD Islam Al-Tarbiyah di Surabaya, kemudian dikembangan dan dibukukan pada tahun 1978 (Siti Sumihatul Ummah dan Abdul Wafi, 2017). Metode ini menggunakan teknik konsentrasi titian ingatan dengan mengelompokkan huruf hijaiyyah dalam struktur kalimat yang mudah diingat, yaitu: (1) mengelompokkan huruf-huruf yang bentuknya sama, (2) mengelompokkan huruf-huruf yang bunyinya sama, (3) mengelompokkan bentuk huruf untuk disambung, (4) mengenalkan huruf sambung dan huruf tunggal terpisah, (5) mengenalkan harakat dan ilmu Tajwid, (6) terakhir mengenalkan huruf hijaiyyah.

Metode keempat, Tilawati. Metode ini diciptakan oleh Hasan Sadzali dan Ali Muaffa, dkk. pada tahun 2002, kemudian dikembangkan di Pesantren Virtual Nurul Falah Surabaya (Dainuri, 2017; Siti Sumihatul Ummah dan Abdul Wafi, 2017). Metode Tilawati menggunakan teknik membaca al-Qur'an individual dan klasikal secara seimbang (. Anak diminta membaca sendiri-sendiri, kemudian guru menyimak bacaan anak, dan kemudian membaca bersama, atau sebaliknya guru meminta anak bersama-sama membaca, kemudian satu-persatu diminta membaca, dan guru menyimak bacaan anak (Ainna Amalia FN dan Cicik Ainurrohmah, 2017).

Metode kelima, Qira'ati. Dahlan Salim Zarkasyi dari Semarang mulai menggunakan metode ini pada tahun 1970-an, kemudian pada tahun 1986 menerbitkan buku enam jilid metode Qiraati (Agung Setiyawan, 2017; Siti Sumihatul Ummah dan Abdul Wafi, 2017). Menurut Agung Setiyawan (2017), Ciri metode Qira'ati adalah: (1) Praktis: langsung tidak 
dieja; (2) Sederhana: kalimat yang dipakai menerangkan itu sederhana tetapi dapat cepat difahami; (3) Sedikit demi sedikit: tidak menambah sebelum lancar; (4) Merangsang anak untuk saling berpacu, (5) Tidak menuntun membaca; (6) Waspada terhadap bacaan yang salah; (7) Teknik drills.

Metode keenam, Iqra. Penciptanya As'ad Humam dari Yogyakarta. Buku modulnya terdiri dari 6 jilid yang sudah populer dan diimplementasikan di Indonesia, terutama di Jawa. Ciri metode ini adalah: bacaan langsung tanpa dieja, menggunakan Cara Belajar Siswa Aktif (CBSA), privat, asistensi, komunikatif, menggunakan modul, praktis, sistematis, variatif, dan fleksibel (Agung Setiyawan, 2017). Metode ketujuh, Iqra Terpadu. Metode ini dikenalkan oleh Tasrifin Karim dari Kalimantan Selatan, menggunakan gabungan metode Iqra dan Barqy, membutuhkan waktu 10 kali pertemuan untuk belajar. Metode kedelapan, Iqra Klasikal. Metode ini merupakan kelanjutan dari Iqra jilid 6 untuk anak SD/MI.

Metode kesembilan, Lamma. Metode ini diciptakan oleh seorang guru al-Qur'an bernama Syahirman dari Kota Padang pada tahun 2004, karena dia merasa tidak puas dengan metode Baghdadi dengan sistem dieja dan membutuhkan waktu banyak. Metode ini diberikan secara individual dan lebih cepat, hanya dalam waktu 15 kali pertemuan beruturut-turut: mengenal fathah, kasrah, dhammah, bacaan berharakat fathah, kasrah, dan dhammah, sukun, tasydid, tanwin, mad, alif saktah, ya mati, waw mati, bacaan tidak terdengar, bacaan berdengung, mim dan nun bertasydid, dan tanda waqaf. Setelah itu latihan bacaan ayat alQuran. Dengan urutan materi tersebut, anak mampu membaca dan menulis dengan cara menjiplak dari tulisan al-Qur'an.

Metode kesepuluh, Nahdhiyyah. Metode ini merupakan inovasi dari metode Baghdadiyah yang disusun oleh sebuah lembaga pendidikan di Tulungagung (Siti Sumihatul Ummah dan Abdul Wafi, 2017; Ahmad Natsir, 2017). Ciri inovasi metode ini dengan mengggunakan alat bantu ketukan untuk mengisyaratkan panjang pendeknya bacaan satu huruf dengan huruf lainnya. Metode ini terbagi ke dalam dua program: (1) Modul untuk mengenal dan praktik membaca al-Qur'an; (2) Sorogan untuk memperlancar bacaan al-Qur'an sampai khatam. Dalam metode ini, anak diharapkan dapat membaca dengan tartil, tahqiq, dan taghanni. Buku modul berjudul "Cepat Tanggap Belajar Al-Qur'an al-Nahdhiyyah”, yang 
disusun pada tahun 1990. Karakteristik metode ini: (1) Materi disusun secara berjenjang dalam buku paket dari jilid 1 - 6. (2) Pengenalan huruf sekaligus diawali dengan latihan dan pemantapan mahkarij huruf; (3) Penerapan kaidah Tajwid dilakukan secara praktis dan dipandu dengan titian murratal; (4) Teknik CBSA; (5) Sistem klsikal; (6) Evaluasi dilakukan secara kontinu.

Metode kesebelas, Wafa. Metode ini dikenal untuk mengembangkan otak kanan, dengan menggunakan pendekatan komprehensif secara bertahap berdasarkan $5 \mathrm{~T}$ yaitu Tilawah, Tahfidz, Tarjamah, Tafhim, dan Tafsir. Metode ini dikembangkan oleh Yayasan Syafaat al-Qur'an (Ratna Pangastuti, 2017). Karakteristik metode Wafa: (1) Menggunakan strategi Tumbuhkan, Alami, Namai, Demonstrasikan, Ulangi, dan Rayakan (TANDUR) diambil dari konsep Quantum Teaching; (2) Menggunakan lagu dalam tilawah dan tahfidz; (3) Hafalan dengan gerakan; (4) Buku berisi tulisan huruf hijaiyyah dan gambar warna-warni; (5) Menggunakan bahasa ibu dalam mengenalkan huruf hijaiyyah sambil diperlihatkan gambar dan gerakan untuk menunjukkan kata yang disebut. Misalnya: (a-da-ma-ta-sa-ya), (ra-ja-ka-yaraya), (na-ma-sa-ya-na-na), (ka-ka-sa-ya-ba-wa-ja-la), dan sebagainya (Siti Rohmaturrosyidah Ratnawati dan Imroatus Solihah, 2017).

Metode kedua belas, Muyassar. Metode ini disusun oleh Ustadz Zakaria al-Hafidz dari Riau (Alucyana, 2017). Karakteristik metode ini: (1) buku terdiri dari dua jilid, (2) disusun dari huruf yang hampir sama bentuknya, (3) disusun dari huruf yang hampir sama bunyinya, (4) menggunakan standar penulisan Rasm Utsmani, (5) pengenalan tajwid hanya dengan simbol, (6) target waktu maksimal 6 bulan, sebanyak 4 pertemuan perminggu @ 75 menit, untuk 10 -13 orang per kelompok.

Metode ketiga belas, Yanbu'a. Penamaan metode ini diambil dari nama lembaga Tahfidz "Yanbu'ul-Qur'an" di Kudus dan Jepara, atas desakan masyarakat, sehingga tersusun metode Yanbu'a dalam kitab “Thariqah Baca Tulis dan Hafal al-Qur'an” oleh Tim penyusun dipimpin K.H. Ulil Albab Arwani pada tahun 2004 (Nur Tanfidiyah, 2017). Secara operasional penerapan metode Yanbu'a sebagai berikut: 
1. Pembukaan. Guru menyampaikan salam sebelum kalam, membaca al-fatihah dan berdo'a pembukaan bersama, absensi, menjelaskan pokok pelajaran yang akan berlangsung. Kegiatan ini berlangsung sekitar 15 - 20 menit.

2. Kegiatan inti. Guru tidak menuntut bacaan anak tetapi membimbing dengan cara: (a) Menjelaskan pokok materi pemelajaran; (b) Memberi contoh yang benar; (c) Menyimak bacaan anak dengan sabar, teliti, dan tegas; (d) Menegur bacaan salah dengan isyarat ketukan, dan lain-lain, bila sudah ditegur masih salah maka diberi contoh yang benar; (e) Jika anak sudah lancar dan benar, guru menaikkan halaman dengan diberi tanda dan ditulis di buku prestasi; (f) Jika anak belum lancar dan masih banyak kesalahan, harus mengulang dengan diberi tanda titik (.) di halaman modul dan di buku prestasi. Kegiatan ini berlangsung selama $30-40$ menit.

3. Penutup. Guru memberi pelajaran tambahan, seperti: hafalan do'a sehari-hari, atau nasehat, kemudian diakhiri dengan membaca doa penutup bersama. Kegiatan ini memakan waktu sekitar 10-15 menit. Dengan demikian waktu belajar untuk tiga kegiatan memakan waktu $60-75$ menit setiap pertemuan.

Metode keempat belas, Ummi. Penamaan metode ini diambil dari lembaga yang mengembangkannya yaitu Ummi Foundation di Surabaya pada tahun 2011 (Siti Sumihatul Ummah dan Abdul Wafi, 2017). Karakteristik metode ini dapat digunakan secara individual maupun klasikal, dipraktikkan langsung tanpa penjelasan panjang lebar, dan dilakukan secara berulang. Buku modul Ummi terdiri dari buku untuk Prasekolah, modul jilid 1 - 6, buku Gharib dan Tajwid. Setiap jilid modul terdapat 40 halaman, terdiri dari pokok pembahasan dan latihan.

Metode kelima belas, Rubaiyat. Metode ini diciptakan oleh Ustadz Hamim Thohari. Penamaan Rubaiyat berarti "empat", di mana metode ini berprinsip serba empat, yaitu: dapat diselesaikan hanya dalam empat pertemuan, setiap pertemuan selama satu jam, sehingga butuh waktu empat jam, dengan cakupan empat materi:

1. Pertemuan pertama, mempelajari huruf hijaiyyah yang disusun berdasarkan kemiripan bentuk, meliputi: (1) Huruf hijaiyyah berdasarkan urutan Baghdadiyah; (2) Huruf hijaiyyah berdasarkan urutan Rubaiyat; (3) Menghafal huruf hijaiyyah Rubaiyyat; (4) Huruf hijaiyyah dalam berbagai bentuk, diakhiri dengan latihan I. 
2. Pertemuan kedua, mempelajari kata sederhana dalam al-Qur'an, meliputi: (1) Membaca tanda vocal a - i- u, (2) Membaca kata vocal an-in-un; (3) Membaca huruf mati dan diftong; (4) Menggandakan bunyi huruf, diakhiri latihan II.

3. Pertemuan ketiga, mempelajari kalimat dalam al-Qur'an dengan nyanyian, meliputi: (1) Membaca kata dengan panjang dua vocal; (2) Membaca kalimat al-Qur'an; menghilangkan bacaan huruf tertentu; (4) Melebur bunyi bacaan, diakhiri latihan III.

4. Pertemuan keempat, mempelajari bacaan unik dalam al-Qur'an, meliputi: (1) Membaca huruf-huruf terpisah di awal surat, (2) Menghentikan bacaan al-Qur'an; (3) berhenti sejenak/saktah; (4) Tanda baca dalam al-Qur'an, diakhiri dengan latihan IV.

Metode keenam belas, Ijmali. Metode ini dikembangkan oleh penulis sendiri, pertama kali dipublikasikan tahun 2017 pada The $2^{\text {nd }}$ Annual Conference on Islamic early Childhood Education di UIN Sunan Kalijaga Yogyakarta. Ijmali dapat diartikan global, keseluruhan, atau utuh. Pemelajaran al-Qur'an dengan metode Ijmali adalah metode keseluruhan, dimulai dari kalimat/ayat utuh, selanjutnya diuraikan per-huruf. Metode Ijmali (deductive) merupakan antonim dari metode Tafshili (inductive). Metode Baghdadi jelas merupakan metode Tafshili, sementara metode Iqra dan Qira'ati merupakan kombinasi Tafshili dan Ijmali. Pemelajaran dengan metode Ijmali langsung dikenalkan kalimat utuh, tidak dieja, kemudian diuraikan perhuruf, sementara dengan metode Tafshili dikenalkan dahulu rincian huruf hijaiyyah sampai anak hafal bentuk dan bunyinya, kemudian dikenalkan harakat fathah, kasrah, dhammah, fathatain, kasratain, dhammatain, sukun, tasydid, mad, waqaf, idzhar, idgham, ikhfa, iqlab, qalqalah, huruf sambung, kalimat utuh.

Berdasarkan pengalaman penulis menggunakan metode Ijmali, anak dapat hanya diajarkan tiga surat al-Qur'an dari juz 30, yaitu Q.S. Al-Fiil, Q.S.Al-Insyirah, dan Q.S. AlFalaq. Dengan dikenalkan tiga surat tersebut, anak dianggap representatif telah mempelajari keseluruhan al-Qur'an, karena dalam tiga surat tersebut telah mencakup 28 huruf hijaiyyah. Dalam Q.S.Al-Fiil terdapat 20 huruf hijaiyyah yang berbeda, dalam Q.S. Al-Insyirah terdapat 6 huruf hijaiyyah yang berbeda, dan dalam Q.S.Al-Falaq terdapat 2 huruf hijaiyyah yang berbeda, sehingga anak sudah mengenal sebanyak 28 huruf hijaiyyah secara lengkap. Artinya, jika anak mampu membaca tiga surat tersebut, anak akan mampu membaca al-Qur'an secara 
keseluruhan. Ketiga surat tersebut dapat dibagi menjadi 7 pertemuan untuk materi baru dan 7 pertemuan untuk pengayaaan setiap selesai mempelajari materi baru.

Berdasarkan studi, penulis menemukan sedikitnya delapan teknik pemelajaran alQur'an, yaitu: Al-Bana, Al-Bayan, Sintetik, Bunyi, Meniru, Kombinasi membaca dan menulis sekaligus, Talqin, dan Membaca Nyaring. Teknik pertama, Al-Bana. Teknik ini diberikan dengan beberapa langkah: (1) Mengenalkan huruf hijaiyyah yang dirangkai secara sederhana dua atau tiga huruf sehingga membentuk kalimat bermakna; (2) Menghafalkan huruf-huruf yang sudah dikenalkan dan menuliskannya; (3) Menganalogikan huruf dengan benda yang sudah dikenal untuk membantu menghafal dan menulis; (3) Mentransliterasi huruf-huruf Arab ke Latin, (4) Memberi kode warna untuk mengidentifikasi setiap materi yang sudah dipelajari (Surasman, 2008). Teknik kedua, Al-Bayan. Teknik ini menggunakan metode Baghdadi klasik dilengkapi visualisasi gambar berwarna yang sudah dikenal untuk memudahkan mengingat. Misalnya mengenalkan huruf s ( س ) dengan gambar "sirup" atau botol sirup, ba-ta ( ) dengan gambar "bata”, dan seterusnya (Ambya Abu Fathin dkk, 2010).

Teknik ketiga, Sintetik (Al-Thariqah al-Tarqibiyyah). Teknik ini dikenal dengan teknik alphabet, yaitu teknik pemelajaran dimulai dengan mengenalkan tulisan huruf-huruf hijaiyyah, kemudian diberi harakat, dirangkai menjadi kalimat sederhana dari dua, tiga, empat huruf secara bertahap. Teknik keempat, Bunyi (Al-Thariqah al-Shautiyyah). Teknik ini dikenalkan dari bunyi huruf, bukan tulisan, dengan diberi contoh, kemudian dirangkai menjadi kalimat bermakna. Teknik kelima, Meniru (Al-Thariqah al-Muhaka atau Musyafahah). Dalam teknik ini anak akan melihat bibir guru mengucapkan bunyi huruf-huruf hijaiyyah, kata per kata dengan benar, kemudian anak menirunya secara berulang, dan guru menyimak yang diucapkan anak hingga benar. Teknik keenam, Kombinasi membaca dan menulis sekaligus (Al-Thariqah al-Jami'ah). Teknik ini menggunakan kombinasi melihat bibir guru saat mengucapkan huruf dan kata per kata, menirunya, menghafal, dan menuliskannya secara variatif (Eko Setiawan, 2017).

Teknik ketujuh, Talqin. Mentalqin adalah membacakan atau mendiktekan. Pemelajaran al-Qur'an dengan teknik ini memadukan antara perbaikan bacaan (tahsin) dan hafalan (tahfidz). Guru mencontohkan bacaan berulang-ulang dengan tartil, lalu anak 
mengikutinya sampai menghasilkan bacaan atau hafalan sebagaimana yang dicontohkan. Teknik ini mulai dikenalkan oleh ustdaz Salafuddin AS dengan cara guru membacakan hafalan kepada anak biasanya tujuh kali, kemudian anak menirukan. Prosedurnya: (1) Memusatkan perhatian pada bacaan; (2) Kenalkan tanda baca dalam al-Qur'an, (3) Mulai dengan pembicaraan ringan; (4) Perdengarkan al-Qur'an berkali-kali, (5) Membaca sedikit demi sedikit, (6) Menghafalkan (https://asy-syaamil.com).

Teknik kedelapan, Membaca Nyaring (Reading aloud). Teknik ini sangat cocok untuk pemelajaran anak usia dini dalam mengembangkan kemampuan bahasa. Bahasa yang diucapkan oleh anak-anak dapat dikontrol dan dikoreksi apabila diucapkan dengan suara nyaring. Teknik Reading aloud di sini bukan berkonotasi pemaksaan kemampuan "membaca" pada anak-anak, tetapi untuk menstimulasi dapat membaca dengan lancar setelah latihan pengucapan yang nyaring. Menurut konsep Jim Trealease (2017), “Teknik Reading aloud bukan mengajarkan anak mampu membaca, tetapi mengajak anak suka membaca". Teknik Reading aloud untuk anak usia dini bertolak dari prinsip: (1) Membaca yang didesain dapat menstimulus think aload pada anak; (2) Membaca yang dapat menumbuhkan keberanian mengucapkan kata, kalimat, dan ide dengan asertif kepada orang lain; (3) Membaca yang dapat mengenalkan literasi awal pada anak; (3) Membaca yang dapat membangun kedekatan anak dengan bacaan; (4) Membaca yang dapat menimbulkan kesukaan/kegemaran anak pada bacaan. Teknik ini digunakan untuk mengajarkan membaca tanpa menulis dan tanpa buku, kecuali lisan anak sendiri. Teknik ini dapat menggunakan metode tertentu, antara lain seperti yang telah dipaparkan di atas.

Dalam penelitian ini, Teknik Reading aloud menggunakan metode Ijmali Prosedur teknisnya: (1) Guru memulai pemelajaran dengan membacakan penggalan ayat dari Q.S. AlFiil dengan tartil, diulang sampai tiga kali, dan anak-anak menyimak; (2) Anak-anak bersamasama mengucapkan dan membaca dengan nyaring kata per kata menirukan yang diucapkan gurunya, diulang sampai tiga kali, (3) Anak-anak satu persatu diminta membacakan, sambil guru menyimak dan merespon aktif bacaan anak.

\section{METODOLOGI}

Penelitian ini menggunakan metode deskriptif kualitatif. Teknik pengumpulan data 
dengan melakukan observasi pelaksanaan pemelajaran al-Qur'an di RA Al-Ishlah Bobos Cirebon dan wawancara dengan guru-gurunya. Objek penelitian adalah siswa RA Al-Ishlah, dan subjek penelitian adalah guru-gurunya. Teknik analisis data dengan mendeskripsikan apa adanya dari pengumpulan data di lapangan dalam bentuk narasi melalui empat tahapan: (1) Eksplorasi data adalah menggali informasi secara detail di lapangan melalui observasi intensif dan wawancara mendalam kepada informan; (2) Reduksi data adalah memilah dan memilih data yang relevan, penting, sesuai dengan focus dan rumusan masalah; (3) Triangulasi data adalah melakukan konfirmasi kepada sumber data primer dan sekunder; (4) Deskripsi data adalah mendeskripsikan data setelah triangulasi, yang diuraikan secara narasi sebagai hasil penelitian, dikuatkan dengan pambahasan hasil temuan empirik dan kajian teoretik.

\section{HASIL DAN PEMBAHASAN}

\section{Keberhasil-gunaan Teknik Reading Aloud}

Berdasarkan hasil observasi dan wawancara menunjukkan, Teknik Reading aloud sangat efektif digunakan dalam pemelajaran literasi awal al-Qur'an untuk anak usia dini, khususnya dalam belajar mengucapkan makharij huruf hijaiyyah, lafadz pendek, ayat, dan surah al-Qur'an.

Berdasarkan hasil observasi dan wawancara dengan guru-guru al-Qur'an menunjukkan, Teknik Reading aloud memudahkan anak belajar mengucapkan makharij huruf hijaiyyah dan membaca lafadz pendek, penggalan ayat dan surah al-Qur'an. Menurut pengakuan seorang guru (Ibu M), anak lebih mudah belajar membaca dengan cara mendengar dan mempraktikkan langsung bacaan dari gurunya. Anak tidak dikenalkan membaca dieja, tulisan transliterasi dari Arab ke Latin, kata atau kalimat selain dari al-Qur'an meskipun berbahasa Arab yang memiliki arti. Di samping itu, lingkungan pesantren cukup kondusif bagi anak-anak untuk pemelajaran al-Qur'an, karena mereka sudah terbiasa dan tidak asing mendengar bacaan al-Qur'an, bahkan hampir semua anak belajar al-Qur'an dari orangtuanya dengan teknik Reading aloud. Dengan begitu, lambat laun anak terbiasa mendengar, mengenal, mengucapkan dan membaca kalimat al-Qur'an setiap hari.

Menurut paparan seorang guru (Ibu St), bahwa faktor guru memegang peranan penting dalam pemelajaran al-Qur'an kepada anak, di samping metode dan teknik. Dalam hal ini, guru 
harus fashih dan benar dalam membaca al-Qur'an sesuai dengan kaidah makharij huruf dan tajwid, termasuk bacaan gharib. Menurutnya, kebetulan di lingkungan pesantren Bobos ini yang paling menonjol dari kemampuan hampir seluruh masyarakatnya, apalagi guru-guru, adalah mampu membaca al-Quran dengan fashih dan benar sesuai kaidah, dan sebagian besar menguasai kaidah bahasa Arab. Latar belakang pendidikan masyarakat di Bobos minimal lulusan Madrasah Aliyah, dengan standar kualitas kemampuan baca tulis Al-Qur'an dan bahasa Arab bagus, di atas rata-rata kualitas lulusan Madrasah Aliyah di kabupaten Cirebon. Di samping itu, keberadaan lembaga pendidikan Tahfidz al-Qur'an di Al-Hikmah yang berdekatan di lingkungan itu, berimbas pada beberapa ibu-ibu ikut belajar tahfidz al-Qur'an.

Sebenarnya guru-guru RA Al-Ishlah tersebut, meskipun sarjana dari PAI dan PAUD, mereka tidak terlalu merisaukan metode dan teknik pemelajaran al-Qur'an yang mana yang efektif, namun setelah ditawarkan metode Ijmali yang mudah diterapkan dengan teknik membaca nyaring yang sudah terbiasa diterapkan, meskipun mereka tidak kenal dengan teknik Reading aloud. Guru mengakui bahwa teknik tersebut sangat efektif bagi anak usia dini dalam pemelajaran al-Qur'an. Dalam menggunakan teknik tersebut, guru selalu menyimak bacaan anak dan merespon aktif dengan memberi kode gerakan atau ucapan, sesuai yang disepakati sebelumnya. Misalnya: kode "ibu jari" untuk menunjukkan bacaan anak benar, dan "kelingking” jika salah. Ucapan Subhanallah atau Allah untuk menunjukkan bacaan anak benar, dan astaghfirullah jika salah. Demikian seterusnya setiap pertemuan.

\section{Keberdaya-gunaan Teknik Reading Aloud}

Berdasarkan wawancara dengan guru-guru, mereka mengakui bahwa teknik yang digunakannya itu sangat efisien dengan beberapa alasan: (1) Efisien karena tidak menghabiskan waktu ber-jam-jam dan tidak berbiaya; (2) Mudah diterapkan karena tidak perlu mempelajari teori dan konsep yang sulit dan rumit yang membutuhkan referensi mutakhir dan banyak; (3) Murah karena tidak membutuhkan biaya, kecuali ketelatenan, kesabaran, dan kesungguhan guru untuk mengantarkan anak-anak mampu membaca al-Qur'an; (4) Simpel karena tidak membutuhkan alat peraga kecuali lisan guru dan anak; (5) Fleksibel dapat digunakan di sekolah atau rumah; (6) Praktis karena langsung dipraktikkan oleh anak; (7) Mudah dan menyenangkan 
bagi anak karena dianggap sebagai permainan kata/bahasa yang berkembang pesat pada anak usia dini.

\section{SIMPULAN}

Berdasarkan hasil penelitian seperti telah dipaparkan di atas, maka dapat disimpulkan bahwa:

1. Teknik Reading aloud sangat efektif digunakan dalam pemelajaran literasi awal al-Qur'an untuk anak usia dini, khususnya dalam belajar mengucapkan makharij huruf hijaiyyah, mapun membaca lafadz pendek, ayat, dan surah al-Qur'an.

2. Teknik Reading aloud sangat efisien digunakan dalam pemelajaran literasi awal al-Qur'an untuk anak usia dini, karena efisien, mudah, murah, simpel, dan fleksibel digunakan oleh guru, dan menyenangkan dirasakan oleh anak usia dini.

\section{DAFTAR PUSTAKA}

Alucyana. (2017). Pemelajaran Al-Qur'an Untuk Anak Usia Dini dengan Metode Muyassar. Yogyakarta: $2^{\text {nd }}$ ACIECE Proceedings.

Amalia, Ainna FN dan Cicik Ainurrohmah. (2017). Implementasi Metode Tilawati dalam Menghafal Bacaan Sholat di TPQ Miftahul Hidayah Gondang Nganjuk. Yogyakarta: $2^{\text {nd }}$ ACIECE Proceedings.

Dainuri. (2017). Problematika Pemelajaran Al-Qur'an dengan Metode Tilawati. Yogyakarta: $2^{\text {nd }}$ ACIECE Proceedings.

Natsir, Ahmad. (2017). Modernisasi Metode Pemelajaran Al-Qur'an Anak Usia Dini: Studi Kasus di TPQ al-Nahdhiyyah Nganjuk. Yogyakarta: $2^{\text {nd }}$ ACIECE Proceedings.

Pangastuti, Ratna. (2017). Pemelajaran Al-Qur'an Anak Usia Dini Melalui Metode Wafa. Yogyakarta: $2^{\text {nd }}$ ACIECE Proceedings.

Ratnawati, Siti Rohmaturrosyidah dan Imroatus Solihah. (2017). Pemelajaran Al-Qur'an Metode Wafa: Sebuah Inovasi Metode Pemelajaran Al-Qur'an dengan Optimalisasi Otak Kiri dan Otak Kanan. Yogyakarta: $2^{\text {nd }}$ ACIECE Proceedings.

Rubaiyat Indonesia. 4 Jam Bisa Baca Al-Qur'an dengan Metode Rubaiyat. Dalam https://www. metoderubaiyat official.com. Diakses 24 Februari 2019. 
Setiawan, Eko. (2017). The Influence of Qur'an Learning Methods and Learning Concentration Toward in Early Reading and Writing the Qur'an Abilities. Yogyakarta: $2^{\text {nd }}$ ACIECE Proceedings.

Surasman. (2008). Metode Al-Bayan. Jakarta: Erlangga.

Tanfidiyah, Nur. (2017). Metode Yanbu'a dalam Meningkatkan Baca Tulis Al-Qur'an pada Anak Usia Dini. Yogyakarta: $2^{\text {nd }}$ ACIECE Proceedings.

Tim Al-Bana. (2010). Metode Al-Bana Belajar Al-Qur'an Secara Mandiri: Mudah Belajarnya, Cepat Bisanya. Jakarta: Bana Publishing.

Tim Asy-Syamil. (2018). Begini Cara Mengajarkan Metode Talqin Al-Qur'an pada Anak. Dalam https://asy-syamil.com. Diakses 24 Februari 2019.

Ummah, Siti Sumihatul dan Abdul Wafi. (2017). Metode-metode Praktis dan Efektif dalam Mengajar Al-Qur'an Bagi Anak Usia Dini. Yogyakarta: $2^{\text {nd }}$ ACIECE Proceedings. 